\title{
EVALUASI IMPLEMENTASI PAK KELUARGA DI GKRI JEMAAT DIASPORA CAWANG JAKARTA TIMUR
}

\author{
Nova Ritonga \\ Djoys Anneke Rantung \\ Universitas Kristen Indonesia \\ novaritonga9@gmail.com \\ djoys.anneke@gmail.com
}

\begin{abstract}
Abstrak
PAK keluarga merupakan pendidikan yang sangat penting bagi seluruh anggota keluarga. Melalui PAK keluarga, seluruh anggota keluarga dapat mengenal dan memahami Allah yang disembah dan memampukan seluruh keluarga hidup sesuai dengan firman Allah serta dapat menjadi teladan bagi sesama. PAK keluarga tidak lepas dari peran orang tua sebagai pribadi yang diberi tanggung jawab oleh Allah dalam mengupayakannya, selain orang tua seluruh anggota keluarga juga memiliki peran yang sangat penting. Untuk itu dibutuhkan komitmen dari seluruh keluarga sehingga PAK keluarga dapat terwujud. PAK keluarga yang telah diimplementasikan perlu dievaluasi secara berkala untuk mengetahui proses dan manfaat implementasi PAK itu sendiri. Evaluasi dilakukan mencakup unsur-unsur PAK keluarga, seperti: pengajar, peserta didik, kurikulum, metode, sarana, lingkungan, dan pendanaan.

Penelitian ini bertujuan untuk melakukan evaluasi terhadap implementasi Pendidikan Agama Kristen (PAK) keluarga di GKRI Jemaat Diaspora Cawang. Penelitian menggunakan metode deskriptif kualitatif dengan pendekatan evaluasi. Model evaluasi yang digunakan adalah model CIPP (context, input, process, dan product). Sampel ditetapkan menggunakan model sampel bertujuan (purposive sampling). Informan dalam penelitian ini berjumlah 10 keluarga yang terdiri orang tua dan anak. Data dikumpulkan dengan menggunakan teknik wawancara, sedangkan teknik analisis data menggunakan model deskripsi analitis.

Dari hasil penelitian ini ditemukan bahwa pemahaman keluarga tentang PAK keluarga sudah memadai. Evaluasi konteks (contect) dihasilkan bahwa pemahaman dan penguasaan orang tua tentang landasan PAK keluarga pada kategori kurang baik, pemenuhan kebutuhan PAK keluarga bagi anak pada kategori baik. Evaluasi masukan (input) ketersediaan pendidik dan peserta didik pada kategori sangat baik (100\%), sarana yang digunakan cukup memadai, orang tua mengetahui berbagai strategi PAK keluarga, perencanaan dana dalam kategori sangat tidak baik.

Evaluasi proses (process) implementasi PAK keluarga berada pada kategori baik, belum memiliki dan menggunakan kurikulum (buku), penggunaan bahan ajar
\end{abstract}


masih minim. Strategi yang digunakan tergolong memadai, dan orang tua berperan dengan baik. Dari evaluasi hasil (product) ditemukan bahwa keluarga memperoleh hasil yang baik. Hasil evaluasi menunjukkan bahwa keluarga belum memahami pentingnya evaluasi implementasi PAK keluarga.

Kata kunci: evaluasi, implementasi, Pendidikan Agama Kristen (PAK) keluarga.

\section{Pendahuluan}

Evaluasi merupakan bagian dari kehidupan manusia. Sadar atau tidak sadar, manusia selalu melakukan evaluasi baik dalam kegiatan sehari-hari maupun dalam pekerjaan. Menurut KBBI, evaluasi adalah penilaian, sedangkan mengevaluasi adalah memberikan penilaian, menilai. ${ }^{1}$ Istilah evaluasi sangat erat kaitannya dengan dunia pendidikan, di mana evaluasi merupakan salah satu cara yang dilakukan untuk mengetahui pelaksanaan pendidikan itu sendiri baik dalam proses pembelajaran maupun kebijakankebijakan pendidikan. Contoh sederhana evaluasi di sekolah: guru memberikan evaluasi kepada peserta didik untuk mengetahui tingkat keberhasilan proses belajar mengajar, mengetahui kemampuan peserta didik, kesesuaian metode yang digunakan, dan lain sebagainya. Sebagaimana pendidikan pada umumnya dievaluasi, maka Pendidikan Agama Kristen (PAK) dalam keluarga juga turut dievaluasi. Hal ini perlu dilakukan untuk melihat pelaksanaan PAK keluarga oleh para orang tua sebagai pelaksanan dan penanggungjawab PAK dalam keluarga serta mengingat sangat pentingnya PAK bagi keluarga Kristen.

Keluarga Kristen adalah keluarga

\footnotetext{
${ }^{1}$ Tim Penyusun Kamus Pusat Pembinaan dan Pengembangan Bahasa, Kamus Besar Bahasa Indonesia (Jakarta: Balai Pustaka, 1996), 272.
}

yang percaya kepada Allah dalam Tuhan Yesus Kristus serta hidup sesuai firmanNya. Keluarga Kristen dipanggil untuk membangun hidup sambil mencerminkan kasih Allah dalam hidup bersama. Keluarga Kristen dibangun atas dasar karya penyelamatan Allah dalam Yesus Kristus yang dikerjakan oleh Roh Kudus. Penyelamatan Allah inilah yang harus diwariskan kepada anak-anak yang diajarkan dalam PAK keluarga. ${ }^{2}$ Keluarga adalah lembaga pertama yang ditetapkan Allah di bumi. Allah mendirikan keluarga agar anak belajar dari orang tua. ${ }^{3}$ Keluarga merupakan pusat pendidikan pertama yang dikenal oleh anak, keluarga memiliki peranan yang sangat penting dalam pendidikan anak dalam segala aspek. ${ }^{4}$ Ketika seorang anak dilahirkan dalam keluarga Kristen, maka ia akan menerima PAK baik dari orang tuanya maupun anggota keluarga lainnya. ${ }^{5}$ Mark Holmen dalam bukunya Church+Home menuliskan bahwa bagi anak-anak, rumah atau

\footnotetext{
${ }^{2}$ Darmawijaya, Mengarungi Hidup

Berkeluarga (Yogyakarta: Kanisius, 2011), 5.

${ }^{3}$ Ibid., 69.

${ }^{4}$ Tim Pengembang Ilmu Pendididikan FIP-UPI, Ilmu dan Implikasi Pendidikan Bagian 4 Pendidikan Lintas Bidang (tk: IMTIMA, 2007), 114.

${ }^{5}$ Robert R. Boehlke, Sejarah Perkembangan Pikiran dan Praktek Pendidikan Agama Kristen Dari Yohanes Amos Comenius Sampai Perkembangan PAK Di Indonesia(Jakarta: BPK Gunung Mulia, 2005), 476.
} 
keluarga merupakan tempat yang tepat untuk mendapatkan pendidikan iman atau PAK. Orang tua harus mengupayakan menghidupkan iman dalam keluarga dan hal ini akan membawa dampak yang sangat besar bagi pribadi anak-anak dan keluarga bahkan gereja. ${ }^{6}$ Inilah tugas penting orang tua yang diberikan Allah, yakni menjamin keberlangsungan PAK dalam keluarga. Beberapa ayat berikut menjadi acuan dalam pelaksanaan PAK keluarga yaitu: Efesus 6:4, 1, Kolose 3:20, Mat. 15:4, Kel. 20:12; 21:17, Ef. 6:2. Ulangan 6:4-9 memberikan gambaran yang cukup jelas tentang bagaimana orang tua harus mengimplementasikan PAK keluarga.

Banyak faktor yang menyebabkan menurunnya implementasi PAK keluarga dalam keluarg-keluarga Kristen masa kini, diantaranya adalah:

1. Hubungan orang tua yang tidak dekat dengan Allah.

2. Pemahaman atau pengetahuan orang tua tentang PAK dan landasan PAK keluarga yang minim.

3. Orang tua tidak memiliki kemampuan dalam mengajarkan PAK.

4. Orang tua tidak punya waktu.

5. Kurangnya minat anak-anak dalam mengikuti PAK keluarga.

Di samping hal-hal di atas, bagian yang penting dalam meningkatkan PAK keluarga adalah melakukan evaluasi terhadap implementasi PAK keluarga. Bagian ini jarang dilakukan oleh keluarga-keluarga Kristen. Keluargakeluarga Kristen yang sudah mengimplemantasikan PAK keluarga merasa cukup sudah melaksanakannya tanpa melalukan evalusi yang cukup terhadap semua unsur PAK keluarga

\footnotetext{
${ }^{6}$ Mark Holmen, Church + Home (Bandung: Pionir Jaya, 2016), 34.
}

yang turut serta dalam mencapai kesuksesan PAK keluarga. Oleh karena itu, jarang ditemukan kurikulum PAK kelurga dan fasilatas penunjang lainnya dalam keluarga yang dapat digunakan untuk implementasi PAK keluarga. Fasilitas yang umum dimiliki dan digunakan keluarga Kristen adalah Alkitab.

\section{Tinjauan Teoritis}

\subsection{Pendidikan Agama Kristen Keluarga}

Pendidikan Agama Kristen merupakan usaha yang dilakukan secara sengaja untuk mendidik orang-orang Kristen untuk memahami dan mengenal agama yang diyakininya serta mengamalkannya dalam kehidupan sehari-hari.

\subsubsection{Pengertian Pendidikan Agama Kristen (PAK)}

Christian education is not an option, it is an order; it is not a luxury, it is a life. It is not something nice to save, it is something necessary to have. It is not a part of the work of the church, it is the work of church. It is not extraneous, it is essential. It is our obligation, not merely an option. ${ }^{7}$ Christian education is the deliberate, systematic, and sustained devine and human effort to share or appropriate teh knowledge, values, attitudes, skill, sensitivities, and behaviors that comprise or are consistent wit the Christian faith. ${ }^{8}$

Samuel Sijabat mengatakan bahwa PAK dapat membentuk kualitas spiritual,

\section{${ }^{7}$ Robert E. Clark, Lin Johnson, Allyn K.} Sloat, Christian Education Foundations for The Future (Chicago: Moody Publishers, 1991), 11.

${ }^{8}$ Robet W. Pazmiño, Foundational Issues in Christian Education 3rd ed. (Amerika: Biker Academic, 2008), 91. 
jiwa dan dapat mempengaruhi dimensi fisik/jasmani manusia. ${ }^{9}$

\subsubsection{Pengertian Keluarga Kristen}

Keluarga Kristen adalah "pemberian" Tuhan yang tak ternilai harganya, keluarga Kristenlah yang memengang peranan yang sangat penting dalam pelaksanaan PAK melebih tugas dan cara-cara yang dilakukan gereja dalam mendidik. ${ }^{10}$ Menurut Mark Holmen keluarga Kristen adalah tempat utama iman ditumbuhkan. ${ }^{11}$ Artinya, keluarga Kristen tidak bisa menyerahkan pelaksanaan PAK hanya kepada gereja dan sekolah, tetapi orang tua harus lebih keras berupaya untuk melaksanakan PAK dalam keluarga. Keluarga Kristen menjadi tempat Injil ditaburkan atau diberitakan, pengajarnya adalah orang tua yang sudah Allah tugaskan sejak dari mulanya dan orang tua bertanggungjawab memelihara pemberitaan itu secara turun temurun. Keluarga Kristen dibangun atas dasar iman dan kepercayaan kepada Allah dalam Kristus Yesus. Hal yang pertama dan yang terutama yang harus dilakukan keluarga Kristen adalah meletakkan dasar yakni pengalaman bersama Allah yang menyelamatkan. Dalam keluarga Kristen harus nyata kasih Allah, hubungan yang dekat dengan Allah baik secara pribadi maupun dalam kehidupan bersama dan menjadikannya gaya hidup.

Merujuk pada uraian di atas (1 dan 2) dapat disimpulkan, PAK keluarga adalah suatu upaya yang dilakukan secara sengaja membelajarkan PAK

${ }^{9}$ B. Samuel Sijabat, Strategi Pendidikan Kristenedisi revisi (Yogyakarta: ANDI, 1996), 115.

${ }^{10}$ Homrighausen dan Enklaar, 128.

${ }^{11}$ Holmen, 38. dalam keluarga untuk mewujudkan keluarga Kristen sejati, yaitu keluarga yang mampu mengimplementasikan imannya dalam kehidupan sehari-hari sebagai gambaran kerajaan Allah yang nyata di bumi di mana orang tua bertindak sebagai pengajar/pendidik dengan tidak menutup kemungkinan anggota keluarga yang lain dapat menjadi pengajar. Orang tua harus menyediakan waktu untuk mengimplementasikan PAK keluarga dan mewariskan iman secara turun temurun dan menjadikan implementasi PAK keluarga lebih dari segala kegiatan yang ada kepada anak-anak.

\subsubsection{Tujuan Pendidikan Agama Kristen (PAK) Keluarga}

John M. Nainggolan menuliskan tujuan PAK keluarga adalah untuk mengajar anak-anak takut akan Tuhan, hidup menurut jalan-Nya, mengasihi Dia, dan melayani Dia dengan segenap hati dan jiwa mereka (Ul. 10:12). Boehlke meringkaskan pendapat Bushnell yang dibagi dalam dua tujuan, yaitu tujuan PAK keluarga bagi anakanak dan tujuan PAK keluarga bagi orang tua. Tujuan PAK keluarga bagi anak-anak adalah "supaya ia menerima kepercayaan dan nilai-nilai yang dianut oleh orang tuanya, belajar bertindak baik, bertumbuh secara wajar dalam iman Kristen sebagai anggota jemaatnya. Sedangkan tujuan PAK keluarga bagi orang tua adalah:

"menyediakan pengalaman belajar yang menolong orang tua mempertimbangkan sejumlah cara mengurus rumah tangga dan dampaknya secara khusus atas pertumbuhan anak, yang melibatkan mereka dalam penelaahan sumber iman Kristen, yang menggiatkannya memilih tindakan yang semakin selaras dengan iman yang mereka 
mengungkapkan secara lisan sehingga mereka lebih mampu menyampaikan iman kepada anaknya. ${ }^{12}$

\subsubsection{Fungsi Pendidikan Agama Kristen (PAK) Keluarga}

Fungsi PAK keluarga adalah:

a. Memperkenalkan Allah dan karyakarya-Nya agar anak-anak dan seluruh anggota keluarga bertumbuh iman percayanya, meneladani Allah dalam hidupnya, serta menghormati firman-Nya sebagai otoritas akhir dalam kehidupan mereka. ${ }^{13}$

b. Menanamkan pemahaman tentang Allah dan karya-Nya kepada anakanak dan seluruh anggota keluarga, sehingga mampu memahami, menghayati, dan mengamalkannya, serta mengikuti-Nya. ${ }^{14}$

c. Menyadarkan anak-anak dan seluruh anggota keluarga akan keberadaannya sebagai ciptaan dan penerima kasih karunia Allah, sehingga mampu mensyukuri segala pemberian Allah (band. Ayb. 1:21; 2:10).

d. Mewujudkan keluarga Kristen sejati ${ }^{15}$ dan mempererat hubungan di antara sesama anggota keluarga.

e. Mempersiapkan anak-anak dan seluruh anggota keluarga supaya mampu mempertahankan imannya di manapun berada dan mampu menjadi 'garam' dan 'terang dunia' (saksi).

f. Menanamkan pemahaman kepada anak-anak tujuan Allah menciptakan

${ }^{12}$ Boehlke, Sejarah Perkembangan Pikiran dan Praktik PAK dari Yohanes Amos Comenisu sampai perkembangan PAK di Indonesia, 501.

${ }^{13}$ Michael J. Antoni, Foundations of Ministry (Malang: Gandum Mas, 2012), 434.

${ }^{14}$ G. Riemer, Ajarlah Mereka (Jakarta: Yayasan Komunikasi Bina Kasih/OMF, 2006), 10.

$$
15 \text { Ibid., } 11 .
$$

dirinya dan menempatkannya dalam dunia.

g. Sebagai pusat bermisi, maksudnya dengan dilakukannya PAK dalam keluarga, anak-anak diajar memiliki iman kepada Yesus Kristus sebagai Tuhan dan juru selamat, anak-anak diselamatkan dan menjadi saksi bagi sesama (terlibat dalam misi). ${ }^{16}$

\subsection{Landasan Pendidikan Agama Kristen Keluarga}

PAK memiliki landasan yang kuat sehingga implementasi PAK dapat terselenggaran dengan baik. Landasan yang dimaksud adalah landasan alkitabiah dan landasan hukum.

\subsubsection{Landasan Alkitabiah}

Landasan alkitabiah PAK keluarga Kristen adalah Alkitab baik Perjanjian Lama dan Perjanjian Baru. Kristianto menyatakan: "dasar teologis PAK adalah alasan alkitabiah tentang pentingnya pengajaran PAK yang terdiri dari tugas, proses, dan tujuan PAK. ${ }^{17}$ Perjanjian Lama dan Perjanjian Baru menjelaskan bagaimana tanggung jawab orang tua dalam mendidik dan mengajar anakanaknya untuk hidup sesuai dengan firman Allah. Tugas pendidikan dan pengajaran dalam keluarga menurut Alkitab (PL dan PB) merupakan tugas yang utama, di mana keluarga merupakan basic utama pendidikan dan pengajaran yang berlangsung terus menerus tanpa mengenal waktu dan tempat. Beberapa ayat berikut sering dijadikan rujukan dalam mengimplementasikan PAK keluarga, yaitu: Efesus 6:4, Matius 19:14; 28:19-

${ }^{16} \mathrm{http}: / /$ sttintheos.ac.id/ejournal/index.php/antusias/article/download/23/2 2, diakses 23 Maret 2018 pkl. 14:37 WIB.

${ }^{17}$ Kristianto, 5. 
20, Amsal 1: 7; 4:13: 10:7, Ulangan 6:49, Mzm. 127:3)

\subsubsection{Landasan Hukum}

Indonesia adalah negara yang mengakui adanya Tuhan, ini tertuang dalam dasar negara Indonesia, Pancasila yaitu sila pertama: "Ketuhanan Yang Maha Esa". Landasan hukum memberi jaminan dan dukungan pada pelaksanaan PAK keluarga sebagai mana yang termuat dalam Undang-Undang Dasar (UUD) 1945, UU RI, dan Peraturan Pemerintah (PP).

1) UUD 1945 bab XI pasal 29 tentang kebebasan beragama. (1) Negara berdasarkan atas Ketuhanan Yang Maha Esa. (2) Negara menjamin kemerdekaan tiap-tiap penduduk untuk memeluk agamanya masingmasing dan beribadah menurut agamanya dan kepercayaannya itu. ${ }^{18}$

2) Undang-Undang Dasar 1945 bab XIII pasal 31 ayat 1 "Setiap warga negara berhak mendapat pendidikan" dan ayat 5 "Pemerintah memajukan ilmu pengetahuan dan teknologi dengan menjunjung tinggi nilai-nilai agama dan persatuan bangsa untuk kemajuan peradaban serta kesejahteraan umat manusia". ${ }^{19}$

3) Undang-Undang RI no 20 tahun 2003 tentang sistem pendidikan nasional, di mana dalam bab II pasal 3, bab VI, dan bab VI bagian kesembilan. Pasal ini memberikan penegasan bahwa PAK dapat dilaksanakan dalam keluarga sebagai pendidikan pada jalur informal. ${ }^{20}$

${ }^{18}$ Weinata Sairin edit, Himpunan Peraturan Dibidang Pendidikan (Jakarta: Jala Permata Aksara, 2010), 18.

19 Ibid., 19.

${ }^{20}$ Weinata Sairin, Peny. Himpunan Peraturan di Bidang Pendidikan (Jakarta: Media Prima Aksara, 2012), 4, 5, 10.
Untuk itu, orang tua yang bertanggungjawab dalam pelaksanaan pendidikan ini.

4) Peraturan Pemerintah (PP) nomor 55 tahun 2007 mengatur tentang pendidikan agama dan pendidikan keagamaan, bab III bagian kedua secara khusus membahas pendidikan keagamaan Kristen yang terdiri dari 4 pasal, yaitu pasal 27 sampai pasal 30, dan pada pasal 27 butir pertama berbunyi "Pendidikan keagamaan Kristen diselenggarakan pada jalur pendidikan formal, nonformal, dan informal". ${ }^{21}$

Adanya jaminan tersebut, maka orang Kristen tidak perlu takut dalam melaksanakan PAK baik di sekolah, gereja dan khususnya dalam keluarga. Pemerintah juga mengharapkan setiap keluarga-keluarga (termasuk keluarga Kristen) mampu membimbing seluruh anggota keluarganya menjadi pribadipribadi yang bertanggungjawab, memiliki iman yang kuat, mampu mengamalkan ajaran agamanya dalam kehidupan sehari-hari, mampu hidup berdampingan dan menjaga kehidupan yang damai dalam masyarakat Indonesia yang majemuk.

\subsection{Implementasi Pendidikan Agama Kristen (PAK) Keluarga}

\subsubsection{Pengertian Implementasi}

Menurut KBBI, implementasi adalah pelaksanaan, penerapan, sedangkan mengimplementasikan adalah melaksanakan, menerapkan. ${ }^{22}$ Sehubungan dengan PAK dalam keluarga, maka implementasi PAK keluarga adalah pelaksanaan atau penerapan PAK dalam keluarga, di mana

\footnotetext{
21 Ibid., 127.

22 Tim Penyusun Kamus Pusat
} Pembinaan dan Pengembangan Bahasa, 374. 
orang tua sebagai pelaksana dan anakanak dan anggota keluarga lainnya sebagai peserta didik. PAK perlu diimplementasikan dalam keluarga supaya PAK bukan sebatas konsep, pengetahuan tetapi PAK yang dihayati dan dilaksanakan dalam kehidupan sehari-hari. PAK memuat segala sesuatu sehubungan dengan keberlangsungan hidup manusia (orang Kristen) untuk itu perlu dibelajarkan. Kebutuhan akan Allah juga dapat terpenuhi melalui implementasi PAK keluarga karena setiap pribadi dibawa dan diarahkan untuk mengetahui, memahami dan mengenal Allah sesuai dengan tujuan PAK itu sendiri yakni membawa peserta didik dalam persekutuan dengan Allah.

\subsubsection{Implementasi Pendidikan Iman Keluarga dalam PL Sebagai Cikal Bakal PAK keluarga}

Praktek Pendidikan Agama Kristen dalam keluarga (PAK keluarga) mengacu pada praktek pendidikan iman dalam Alkitab, yakni Perjanjian Lama (PL) dan Perjanjian Baru (PB) di mana tokoh-tokoh PL memiliki ketaatan kepada Allah dengan membawa seluruh keluarganya untuk tetap menyembah Allah. E.G. Homrighausen dan I.H. Enklaar berpendapat bahwa PAK berpangkal pada persekutuan umat Tuhan dalam PL. Menurut mereka, PAK dimulai sejak Allah memilih dan memanggil Abraham menjadi umat pilihan-Nya yang kemudian menjadi nenek-moyang orang percaya/umat pilihan Allah. Mereka juga meyakini bahwa pokok pengajaran PAK adalah Allah yang sekaligus menjadi guru Agung bagi umat-Nya yang terdapat dalam PL. Orang-orang Kristen juga mengaku bahwa PL merupakan bagian dari pengajaran Kristen. ${ }^{23}$

Praktik pendidikan iman dalam keluarga jelas terlihat dalam Ulangan 6:4-9 (pendidikan iman dilakukan kapan saja dan di mana saja), Mazmur 78:3-7 orang tua bertanggungjawab meneruskan pengajaran yang sudah mereka terima dari orang tua/keluarga sebelumnya kepada anak-anak mereka, generasi berikutnya terutama dengan cara lisan. Tradisi lisan ini menceritakan segala perbuatan Allah. ${ }^{24}$ Berikut ayat-ayat yang menunjukkan pentingnya pendidikan iman Keluaran 20:1-17; 21; 12:24-27, Yosua 4:6-7, Amsal 22:6; Mazmur 119:11,105; Hosea 4:6.

Kurian dan Lamport dalam Enciklopedia of Christian Education mengemukakan beberapa bentuk pendidikan iman keluarga dalam PL:

1) Menjawab pertanyaan yang diajukan anak-anak. Orang tua wajib menjawab pertanyaan anak-anak yang menanyakan segala sesuatu yang merupakan tanda peringatan akan segala perbuatan Allah bagi bangsa Israel (Ul. 6:20-25, Kel. 12:25-27, Yos. 4:6, 21). ${ }^{25}$

2) Keikutsertaan dalam persekutuan. Keluarga-keluarga dalam PL ikut serta dalam persekutuan/perayaanperayaan hari raya, seperti hari raya Purim, hari raya Sabat dan hari raya Paskah dengan mengikutsertakan anak-anak. ${ }^{26}$

3) Doa keluarga. Doa dipanjatkan untuk kelangsungan keluarga (band. Kej. $17: 18,20 ; 24: 12-14 ; 32: 9-12) .{ }^{27}$

4) Menanamkan kebijaksanaan. Kitab Amsal menjadi "buku pegangan

\footnotetext{
23 Homrighausen dan Enklaar, 1.

24 Reimer, 37.

25 Kurian dan Lamport, 441.

${ }^{26}$ Ibid.

${ }^{27}$ Ibid.
} 
tertua" dalam mendidik anak yang terdiri dari 31 pasal, di mana di dalamnya memuat ajaran tentang kejujuran, kerendahan hati, kebaikan keadilan, kesucian, dan penguasaan diri. Menurut mereka tujuan utama orang Ibrani adalah memberikan kebijaksanaan kepada anak-anaknya tentang urusan praktis kehidupan melalui pengajaran yang dilukiskan dalam Kitab Amsal. ${ }^{28}$

5) Latihan kesucian. Umat pilihan Allah harus menjaga kesucian hidupnya, berbeda dengan bangsa-bangsa lain. Ketika keluarga mempersiapkan korban Paskah, ikut serta dalam makan Sabat, atau dalam hal menaati perjanjian sunat, anak-anak belajar bahwa umat Allah harus berbeda dan terpisah dari bangsa-bangsa lain di sekitarnya (band. Mzm. 106:3437). ${ }^{29}$

Harus diakui bahwa PL tidak banyak menceritakan secara gamblang praktik pendidikan iman dalam keluarga. Praktik pendidikan iman yang umum ditemukan adalah pendidikan dalam persekutuan umat Allah. Meskipun demikian, berikut beberapa keluarga yang dapat menunjukkan manfaat dari pendidikan iman dalam keluarga:

a) Keluarga Adam (Kej. 4:3-4). Kain dan Habel mempersembahkan korban kepada Allah. Ini menunjukkan bahwa Adam dan Hawa telah mendidik anak-anaknya untuk beribadah kepada Allah yang telah menciptakan mereka. Setiadarma mengatakan: orang tua menjadi sumber belajar bagi anakanak. ${ }^{30}$

\footnotetext{
28 Ibid., 442.

29 Ibid.

${ }^{30}$ Monty P. Satiadarma, Persepsi
} Orangtua Membentuk Perilaku Anak: Dampak b) Keluarga Abraham, Ishak dan Yakub (Kej. 17:12, 13, 23; 12:7, 8; 13:4, 18; $22: 9 ; 26: 25 ; 28: 1)$. Homrighausen dan Enklaar mengatakan bahwa Yakub tetap hidup sesuai didikan orang tuanya walaupun ia tinggal jauh dari orang tuanya. ${ }^{31}$ Homrighausen dan Enklaar mengatakan bahwa didikan yang diterima Yusuf dalam keluarga ayahnya dan yang tertanam dalam jiwanya berpengaruh besar dalam kehidupannya baik saat ia sebagai budak di Mesir, baik saat ia dalam penjara, maupun setelah ia menjadi orang nomor dua di tanah Mesir, yakni Yusuf tetap hidup takut akan Allah dan selalu ingat akan keluarganya (Kej. 37, 38-50). ${ }^{32}$

c) Keluarga Ayub (Ayub 1:1, 5). Ayub mengajarkan iman dan rasa takut akan Allah kepada keluarganya melalui teladan hidupnya yang saleh, jujur dan takut akan Allah, praktek peribadatan yakni dengan mengajak anak-anaknya, menguduskan mereka dan mempersembahkan korban kepada Allah.

\subsubsection{Implementasi Pendidikan Iman Keluarga dalam Perjanjian Baru}

Praktik pendidikan iman dalam Perjanjian Baru (PB) selanjutnya menjadi praktik PAK dalam keluarga Kristen juga tidak dituliskan secara deteil atau rinci, yakni bagaimana orang tua mendidik anak-anak mereka untuk tetap hidup takut akan Allah. Meskipun demikian, gambaran tentang pelaksanaan dan praktik pendidikan iman dan PAK dalam keluarga dapat diketahui dari

Pygmalion di dalam Keluarga (Jakarta: Yayasan Pustaka Obor Indonesia, 2001), 101.

${ }_{31}^{31}$ Homrighausen dan Enklaar, 129. 
beberapa keluarga yang memberikan perhatian terhadap iman keluarganya. Keluarga-keluarga tersebut antara lain:

a. Keluarga Yusuf, orang tua jasmani Yesus (Luk. 2:21-24; 2:41-52, Yoh. 8:2). Homrighausen dan Enklaar pun mencatat bahwa keluarga Yusuf termasuk dalam keluarga yang hidup saleh dalam PB. ${ }^{33}$

b. Keluarga Orang tua Timotius ( 1 Tim. 4:13). Iman yang dimiliki oleh Timotius adalah warisan yang diperolehnya dari neneknya Lois dan ibunya Eunike yang hidup saleh di Listra (2 Tim. 1:5). ${ }^{34}$

Selain keluarga-keluarga di atas, Homrighausen dan Enklaar mencatat beberapa keluarga yang hidup saleh yang dicatat dalam Alkitab, yaitu keluarga Maria, Marta dan Lazarus di Betania, Keluarga Yohanes Markus dan ibunya di Yerusalem, keluarga Lidia di Filipi. ${ }^{35}$

\subsubsection{Implementasi PAK Keluarga Masa Kini}

Setelah kekristenan muncul atau dikenal, muncullah agama Kristen. Untuk memenuhi kebutuhan rohani anak dan seluruh anggota keluarga, maka keluarga-keluarga Kristen melaksanakan PAK dalam keluarga (PAK keluarga) berdasar pada Alkitab. Implementasi PAK keluarga masa kini dipengaruhi oleh praktik iman keluarga dalam PL dan PB serta praktik PAK keluarga sebelumnya baik yang diperoleh dari keluarga sendiri (orang tua) maupun dari keluarga orang lain. Implementasi PAK keluarga dilakukan dalam dua model, yaitu terstruktur dan tidak terstruktur. Terstruktur menurut KBBI adalah "sudah dalam keadaan disusun dan

\footnotetext{
${ }^{33}$ Homrighausen dan Enklaar, 130.

34 Ibid.

${ }^{35}$ Homrighausen dan Enklaar, 130.
}

diatur rapi", ${ }^{36}$ jadi PAK keluarga terstruktur adalah PAK keluarga yang sudah disusun dan diatur termuat dalam kurikulum, sedangkan PAK keluarga tidak terstruktur adalah PAK keluarga yang tidak disusun atau diatur, artinya PAK berjalan secara natural.

(a) PAK Keluarga Terstruktur

PAK keluarga terstruktur adalah PAK keluarga yang sudah direncanakan dan ditentukan waktu, tempat, topik pembelajran, sarana yang digunakan, dan jika membutuhkan dana, dibuat anggaran dananya. Menurut Kristianto ada dua hal penting yang harus dilakukan keluarga untuk mewujudkan pertumbuhan rohani keluarga, yaitu kebaktian keluarga dan saat teduh. Sedangkan menurut Rupp, banyak kegiatan yang bisa dilakukan terkait pelaksanaan PAK keluarga, seperti: malam keluarga, ${ }^{37}$ perayaan keluarga: merayakan wisuda, ${ }^{38}$ hari lahir atau hari adopsi, ${ }^{39}$ merayakan masa sengsara, ${ }^{40}$ merayakan kebangkitan, ${ }^{41}$ merayakan natal, ${ }^{42}$ merayakan 14 Februari (Valentine), ${ }^{43}$ perayaan pentakosta, ${ }^{44}$ merayakan pengucapan syukur. ${ }^{45}$

Selain berbagai kegiatan di atas,

${ }^{36}$ Tim Penyusun Kamus Pusat

Pembinaan dan Pengembangan Bahasa, Kamus

Besar Bahasa Indonesia, ed. 3-cet. 1 (Jakarta:

Balai Pustaka, 2001), 1092.

37 Anne Neufeld Rupp, Tumbuh-

Kembang Bersama Anak: Menuntun Anak Menuju Pertumbuhan Emosional, Moral, dan iman (Jakarta: BPK Gunung Mulia, 2009), 15.
${ }^{38}$ Ibid., 17
39 Ibid., 66.
${ }^{40}$ Ibid., 109.
41 Ibid., 129.
42 Ibid., 170.
43 Ibid., 192.
44 Ibid., 213.
45 Ibid., 233. 
keluarga juga dapat memasang tulisan ayat-ayat Alkitab atau simbol-simbol kekristenan di rumah (Ul. 6:8-9), mengajak anggota keluarga beribadah ke gereja, mengadakan retret keluarga dan lain sebagainya. Mengingat PAK keluarga merupakan hal yang sangat penting, maka keluarga harus melakukannya setiap hari, ${ }^{46}$ menentukan waktu-waktu pelaksanaan masingmasing kegiatan, harus direncanakan dengan baik dan matang serta dipersiapkan dengan baik. Ada pribahasa yang tepat untuk menggambarkan betapa pentingnya doa bersama bagi keluarga, yaitu: "The family that pray together, stay together" artinya, keluarga yang berdoa bersama, tetap utuh. ${ }^{47}$

(b) PAK Keluarga Tidak Terstruktur

PAK keluarga tidak terstruktur adalah PAK keluarga yang dilakukan namun tanpa perencanaan terlebih dahulu, hal itu terjadi secara spontan dan natural, misalnya: ketika anak-anak melakukan kesalahan, orang tua langsung menasehati anak dengan memuat PAK di dalamnya, atau pada saat dalam perjalanan dan melihat sesuatu hal, orang tua langsung mengajarkan PAK pada anaknya saat itu juga.

Bukan hal yang mudah untuk mengimplementasikan PAK keluarga baik secara terstruktur maupun PAK keluarga tidak terstruktur. Ada banyak faktor yang membuat keluarga gagal melaksanakan PAK keluarga. Menurut Setiawan, ada lima faktor yang membuat

\footnotetext{
${ }^{46}$ Setiawani, 191.

${ }^{47}$ Richard M. Daulay, Menganal Gereja Methodis Indoensia (Jakarta: BPK Gunung Mulia, 2004), 175.
}

ibadah keluarga tidak terlaksana, yaitu: ${ }^{48}$

1) Bisa dibatalkan.

2) Suasana Mati atau ibadah monoton.

3) Menyelewengkan Tujuan.

4) Kurang Mengikutsertakan Anak.

5) Menuntut Terlampau Tinggi.

Selain beberapa faktor di atas, ada beberapa faktor lain yang dapat menggagalkan implementasi PAK keluarga, antara lain:

a. Tidak Ada Waktu. ${ }^{49}$

b. Sumber Daya Manusia (kemampuan orang tua) yang terbatas.

c. Belum memiliki kurikulum dan bahan ajar PAK keluarga sendiri.

d. Faktor Tujuan, kurangnya pemahaman orang tua akan tujuan implementasi PAK keluarga.

Menyikapi faktor-faktor yang menggagalkan terlaksananya PAK keluarga, maka diperlukan strategi agar PAK keluarga tetap terlaksana. Strategi yang dapat digunakan adalah:

1) Memberikan pemahaman mendalam kepada orang tua akan arti dan tujuan implementasi PAK keluarga.

2) Mengingatkan terus menerus akan tugas dan tanggung jawab keluarga khususnya orang tua untuk mendidik anak baik jasmani dan rohani (Ef. 6:4, Ul. 6:4-9).

3) Keluarga membangun komitmen untuk tetap melaksanakan PAK keluarga dalam situasi apapun dan menjadikannya gaya hidup. ${ }^{50}$

4) Orang tua meningkatkan kemampuannya dalam segala hal, baik pengetahuan Alkitab, metode mengajar, psikologi perkembangan anak, dan lain sebagainya yang dibutuhkan untuk dapat melaksanakan PAK keluarga secara

\footnotetext{
${ }^{48}$ Setiawani, 192.

49 Setiawani, 193.

50 Setiawani, 193.
} 
optimal.

5) Menciptakan suasana PAK keluarga yang menyenangkan. ${ }^{5}$

6) Merancang dan membuat kurikulum dan bahan ajar sendiri sesuai dengan kebutuhan keluarga.

\subsubsection{Unsur-unsur PAK Keluarga}

Unsur-unsur yang terkandung dalam PAK keluarga antara lain:

\section{(a) Pendidik/Pengajar}

Pendidik adalah orang yang bertugas untuk mendidik atau mengajar. Pengajar PAK keluarga adalah orang tua yang diberi Allah wewenang dan tanggung jawab untuk mendidik. Menurut Sijabat, pendidik harus memiliki keseimbangan antara persyaratan profesional dan persyaratan rohani, yaitu lahir baru, dewasa rohani, serta berpegang pada Alkitab sebagai sumber utama pengajaran. ${ }^{52}$ Efesus $6: 4{ }^{53}$ menyatakan bahwa pendidik dalam keluarga adalah ayah. Menurut Bushnell, seperti yang dikutip Boehlke menyatakan pendidik PAK terdiri dari orang tua, jemaat sendiri, pendeta dan anak-anak. $^{54}$

\section{(b) Peserta Didik}

Peserta didik adalah orang yang menerima PAK keluarga. Seluruh anggota keluarga dapat menjadi peserta

51 Ibid

52 B.S. Sidjabat, Menjadi Guru yang Profesional: Sebuah Perspektif Kristiani (Bandung: Kalam Hidup, 2000), 52.

${ }^{53}$ Efesus 6:4 "Dan kamu, bapa-bapa, janganlah bangkitkan amarah di dalam hati anakanakmu, tetapi didiklah mereka di dalam ajaran dan nasehat Tuhan."

54 Boehlke, Sejarah Perkembangan Pikiran Dan Praktek Pendidikan Agama Kristen Dari Yohanes Amos Comenius Sampai Perkembangan PAK Di Indonesia, 502. didik. Menurut John Calvin, PAK adalah pendidikan yang bertujuan mendidik semua putra-putri gereja. ${ }^{55}$ Dari pernyataan ini dapat ditarik kesimpulan, peserta didik PAK keluarga adalah anak. Sedangkan menurut Homrighaussen, tujuan PAK adalah pelajar muda dan tua. ${ }^{56}$ Artinya, peserta PAK keluarga adalah orang muda dan tua.

(c) Kurikulum

Keluarga perlu memiliki kurikulum PAK karena kurikulum berfungsi sebagai pedoman dan panduan/pegangan pendidik dalam mengajar. ${ }^{57}$ Kurikulum PAK keluarga adalah tata cara atau prosedur yang disusun dan dipakai di mana di dalamnya terdapat materi ajar atau bahan ajar yang merupakan pengalaman belajar peserta didik untuk mencapai tujuan PAK keluarga. Oleh sebab itu, kurikulum yang akan digunakan perlu rancang atau disusun disesuaikan dengan tujuan dan kebutuhan setiap keluarga. kurikulum yang diterapkan oleh lembaga Kristen, keluarga, gereja dan sekolah haruslah kurikulum kebenaran Allah, di mana setiap peserta didik dihantar untuk belajar dan menemukan kebenaran Allah, yakni kebenaran yang dinyatakan melalui hukum alam dan melalui pewahyuan, yaitu firman Allah (Alkitab). ${ }^{58}$ Robert W. Pazmiño mengatakan dalam menyusun kurikulum perlu menggabungkan atau

$$
\begin{aligned}
& { }_{56}^{55} \text { Kristianto, } 2 . \\
& { }_{56}^{56} \text { Kristianto, } 4 . \\
& { }_{58}^{57} \text { Sudin, 20. }
\end{aligned}
$$

http://repository.petra.ac.id/15665/1/pdfKarakter_Pendidikan_Kristen_MAGDA_to_PK. pdf, 10. Diaskses Rabu, 04 April 2018 pukul 13:40 WIB. 
mencampurkan antara konten Kristen ${ }^{59}$ dan pengalaman sehingga pikiran dan kehidupan peserta didik dapat dipengaruhi dan diubahkan oleh kebenaran Allah. Sedangkan LeBar mengatakan konten Kristen tanpa disertai pengalaman adalah kosong dan pengalaman tanpa disertai konten Kristen adalah buta. Menurutnya kedua hal ini harus berjalan bersama-sama. Kurikulum yang efektif adalah kurikulum yang di dalamnya terdapat konten dan pengalaman kristiani, maka kurikulum akan berpotensi mengubah kehidupan (transformasi). ${ }^{60}$

Miller mengatakan kurikulum terdiri dari tiga ruang lingkup yaitu: Alkitab-sentris, bahan-sentris, dan kehidup/pengalaman-sentris. Alkitabsentris berisi: penciptaan, perjanjian, penebusan, persekutuan, dan penggenapan; bahan-sentris berisi: bahan Alkitab, pentingnya gereja, dan teologi; kehidupan/pengalaman-sentris berporos pada kebutuhan yang perlu dipenuhi seperti bertindak, mengetahui, dan mempercayai. ${ }^{61}$ Sedangkan menurut Donald Grrigs seperti yang dikutip Sumiyatiningsih menyatakan minimal terdapat 10 aspek kurikulum, yaitu: 1) Materi ajar atau apa yang akan diajarkan, 2) Kompetensi capaian, 3) Kegiatan atau aktivitas belajar, 4) Sumber-sumber belajar, 5) Strategi yang akan digunakan,

${ }^{59}$ Konten dalam pengajaran Kristen adalah kebenaran yang dinyatakan dalam Kristus Yesus dan Alkitab melalui pekerjaan Roh Kudus dan kebenaran yang bisa dilihat dalam seluruh ciptaan.

${ }^{60}$ Robert W. Pazmiño, Fondasi

Pendididkan Kristen: Sebuah Pengantar dalam Perspektif Injil (Bandung: STT Bandung dan BPK Gunung Mulia, 2012), 211-212.

${ }^{61}$ Boehlke, Sejarah Perkembangan Pemikiran dan Praktik PAK dari Yohanes Amos Comenius sampai Perkembangan PAK di Indonesia, 755.
6) Lingkungan atau tempat pembelajaran, 7) Pertanyaan yang akan ditanyakan kepada peserta didik, 8) Pilihan-pilihan alternatif kegiatan, 9) Arahan-arahan yang diberikan kepada peserta didik untuk menolong mereka dalam aktivitas belajar, dan 10) Umpan balik dari pendidik atau penguatan. ${ }^{62}$ Kurikulum perlu bahkan wajib ditinjau, diperbaharui dan dievaluasi sehingga selalu sesuai dengan kebutuhan.

(d) Bahan atau Materi Ajar

Bahan atau materi ajar adalah unsur yang pokok dalam proses pendidikan. Bahan atau materi ajar yang digunakan disesuaikan dengan kebutuhan peserta didik. Sumber utama yang menjadi bahan dan materi ajar PAK keluarga adalah Alkitab, di samping Alkitab, keluarga dapat menggunakan sumber dan bahan ajar lain seperti Renungan Harian, buku-buku Kristen (teologi, PAK, biografi, buku cerita anak dan kesaksian), video, peristiwa kehidupan, alam semesta, dan lain sebagainya.

Beberapa topik yang dapat dibelajarkan dalam melaksanakan PAK keluarga baik dalam PAK keluarga terstruktur mau pun PAK keluarga tidak terstruktur:

1) Allah mengasihi setiap orang.

2) Allah mengharapkan setiap orang mengasihi-Nya.

3) Orang berdosa tidak mendengarkan perkataan Allah.

4) Yesus mati untuk setiap orang.

5) Yesus adalah juruselamat setiap orang.

6) Setiap orang berdosa.

7) Setiap orang yang berdosa perlu

${ }^{62}$ Dien Sumiyatiningsih, Mengajar dengan Kreatif dan Menarik (Yogyakarta: ANDI, 2012), 56-60. 
juruselamat.

8) Kematian Tuhan Yesus menjauhkan hukuman Allah dari yang berdosa.

9) Yesus ingin kita memberitakan Injil kepada orang lain.

10) Yesus ingin kita berdoa dan mempersembahkan uang untuk pekerjaan misi. $^{63}$

\section{(e) Tujuan}

Tujuan PAK keluarga bagi anak adalah "supaya ia menerima kepercayaan dan nilai-nilai yang dianut oleh orang tuanya, belajar bertindak baik, bertumbuh secara wajar dalam iman Kristen sebagai anggota jemaatnya."64 Sedangkan tujuan PAK keluarga bagi orang tua adalah "menyediakan pengalaman belajar yang menolong orang tua mempertimbangkan sejumlah cara mengurus rumah tangga dan dampaknya secara khusus atas pertumbuhan anak, yang melibatkan mereka dalam penelaahan sumber iman Kristen, yang menggiatkannya memilih tindakan yang semakin selaras dengan iman yang mereka mengungkapkan secara lisan sehingga mereka lebih mampu menyampaikan iman Kristen kepada Anak."65 Dengan memahami tujuan PAK keluarga, maka keluarga dapat bekerjasama untuk mewujudkan PAK keluarga dengan segala daya upaya.

\section{(f) Aktivitas Belajar}

Aktifitas pembelajaran PAK keluarga dapat dilakukan kapan saja dan di mana saja, karena pada dasarnya PAK tidak terpisah dari kegiatan keseharian keluarga. Boehlke menyatakan melalui aktifitas belajar peserta didik mengalami

\footnotetext{
${ }^{63}$ Setiawani, 190.

64 Ibid., 501.

65 Ibid.
}

perjumpaan dengan Allah, menyadari akan tindakan Allah di tengah-tengah kehidupannya, mengetahui peristiwaperistiwa yang terjadi atas karya Allah dan respon manusia, memahami karya Allah pada masa lalu dan hubungannya dengan kehidupan masa kini, dan memahami seluruh pengalaman kehidpan kristiani. ${ }^{66}$

(g) Metode

Dalam mengimplementasikan PAK keluarga dibutuhkan metode yang tepat. Menurut Homrighausen dan Enklaar sehubungan dengan PAK mendefenisikan metode adalah "suatu pelayanan, suatu pekerjaan yang aktif, yang kita lakukan bagi Firman Tuhan dan sesama manusia, supaya kedua pihak dapat bertemu satu sama lain", 67 melalui metode peserta didik benarbenar belajar firman Tuhan yang akan mengubah mereka baik dalam pengetahuan, sikap, nilai-nilai maupun tingkah laku sehingga sesuai dengan firman Tuhan, ${ }^{68}$ namun metode hanyalah jalan dan alat saja, bukan tujuan. Dihubungkan dengan implementasi PAK keluarga, metode adalah suatu cara atau alat yang digunakan oleh orang tua sebagai strategi dalam membelajarkan atau melaksanakan PAK dalam keluarga untuk mencapai tujuan yang sudah ditetapkan.

Brotosudarmo berpendapat ada 20 metode yang bisa dipakai dalam pembinaan warga gereja, ${ }^{69}$ menurut Daniel Nuhamaran dalam membelajarkan PAK ada tujuh metode

${ }^{66}$ Boehlke, Sejakar Perkambangan Pikiran dan Parkatik PAK dari Yohanes Amos..., 559-560.

${ }^{67}$ Homrighausen dan Enklaar, 74.

${ }^{68}$ Nuhamara, 135.

${ }^{69}$ Brotosudarmo, 119-126. 
yang dapat dipakai, dan Nainggolan hanya menuliskan 16 metode. ${ }^{70}$ Metodemetode tersebut dapat digunakan dalam mengimplementasikan PAK keluarga. PAK dalam keluarga dilakukan dengan sosialisasi dan edukasi secara bersamaan sesuai perkembangan kepercayaan anak.

\section{(h) Lingkungan}

Lingkungan atau tempat pelaksanaan pendidikan merupakan unsur yang perlu diperhatikan dalam proses pendidik karena lingkungan juga memiliki peran penting. Orang tua perlu memperhatikan lingkungan tempat keluarga tinggal, kebiasaan masyarakat sekitar dan lokasi pelaksanaan PAK keluarga khususnya PAK keluarga terstruktur. Secara umum, PAK keluarga dapat dilakukan di mana saja sebagaimana pendidikan dapat dilakukan di mana saja. ${ }^{11}$

\section{(i) Sarana dan Prasarana}

Sarana dan prasarana adalah segala sesuatu yang digunakan untuk mendukung proses pendidik baik berupa materi maupun non materi. Menurut GP "orang tua wajib memfasilitasi pelaksanaan PAK keluarga untuk terlaksananya keberhasilan kurikulum dan tercapainya tujuan". ${ }^{72}$ Sarana dan prasana merupakan unsur yang perlu diperhatikan oleh orang tua karena dengan adanya sarana dan prasarana yang memadai akan sangat menunjang keberlangsungan implementasi PAK keluarga. Sarana dan prasarana yang

\footnotetext{
${ }^{70}$ John M. Nainggolan, Menjadi Guru Agama Kristen (Bandung: Gerakan Infomedia, 2006), 44-52.

${ }^{71}$ Andri Rizki Putra, Orang Jujur Tidak Sekolah (Yogyakarta: Penerbit Bentang, 2014), 147.

$$
{ }^{72} \text { GP, } 75 .
$$
}

umum digunakan antara lain: rumah, meja, kursi, Alkitab, buku-buku, pulpen, alam, alat peraga, alat musik, binatang, gambar, tanaman, dan lain sebagainya. Menurut Setiawan, sarana yang dapat digunakan dalam melaksanakan PAK keluarga diantaranya: Alkitab, gambargambar dari kisah Alkitab, kaset atau lagu, video rohani. ${ }^{73}$ Orang tua harus kreatif dalam memanfaatkan sarana dan prasarana yang ada, karena ada banyak sarana yang dapat digunakan tanpa harus mengeluarkan biaya.

\section{(j) Pendanaan/Dana \\ Dalam mengimplementasikan} PAK keluarga tentunya membutuhkan dana, untuk itu orang tua sebagai penanggungjawab PAK keluarga harus memikirkan pendanaan atau dana yang akan digunakan. Orang tua yang menginginkan PAK keluarga berjalan dengan lancar dan tujuan PAK keluarga tercapai dengan optimal, maka dana yang akan digunakan harus diperhatikan dan dianggarkan sesuai dengan kebutuhan. Sebagaimana keluarga menyediakan dana untuk kebutuhan lain, maka dana untuk PAK keluarga juga perlu disediakan. Dana dibutuhkan untuk memenuhi kebutuhan pelaksanaan PAK keluarga, seperti membeli alat peraga, buku cerita, Alkitab anak, buku gambar, pencil warna, biaya retret keluarga, konsumsi, dan lain sebagainya. Dengan adanya anggaran dana, keluarga akan dengan mudah melaksanakan PAK keluarga yang sudah direncanakan.

\subsection{Stategi Implementasi PAK Keluarga}

Strategi adalah "rencana yang cermat mengenai kegiatan untuk

\footnotetext{
${ }^{73}$ Setiawan, 192-193.
} 
mencapai sasaran khusus". ${ }^{74}$ Untuk mencapai sasaran atau tujuan PAK keluarga, orang tua harus memiliki strategi yang cermat dan tepat. Strategi yang digunakan disesuaikan dengan situasi dan kondisi, selain itu orang tua juga harus memahami keberadaan peserta didik yang turut serta dalam pelaksanaan PAK keluarga.

Beberapa strategi yang dapat digunakan dalam mengupayakan PAK keluarga, yaitu:

a. Memahami dan Menguasai Karakteristik Peserta Didik

b. Memahami PAK keluarga dan Prinsip-prinsip Pembelajaran yang Mendidik

c. Pendekatan Personal dengan Peserta Didik

d. Memiliki komunikasi yang Baik dengan Peserta Didik

e. Memilih Materi PAK keluarga yang Tepat

f. Keteladanan Hidup

\section{Evaluasi Pendidikan Agama Kristen Keluarga}

Dalam dunia pendidikan evaluasi merupakan bagian yang sangat penting, sebagai salah satu cara yang dilakukan untuk melihat, menilai mutu dan pelaksanaan pendidikan. Hal-hal yang dievaluasi juga cukup beragam, seperti proses pembelajaran, kurikulum, materi ajar, sarana dan prasarana yang digunakan, pendanaan, dan lain sebagainya.

\subsection{Pengertian, Tujuan dan Fungsi Evaluasi Pendidikan}

\subsubsection{Pengertian Evaluasi Pendidikan}

Evaluasi pendidikan adalah

${ }^{74}$ Tim Penyusun Kamus Pusat

Pembinaan dan Pengembangan Bahasa, Kamus Besar Bahasa Indonesia, ed. 2, 964. "kegiatan menilai yang terjadi dalam kegiatan pendidikan". Dalam proses penilaian terdapat input, proses/transformasi, dan output/hasil. ${ }^{75}$ Menurut UU No. 20 tahun 2003 tentang Sistem Pendidikan Nasional bab I pasal 1 ayat 21 , evaluasi pendidikan adalah kegiatan pengendalian, penjaminan, dan penetapan mutu pendidikan terhadap berbagai komponen pendidikan pada setiap jalur, jenjang, dan jenis pendidikan sebagai bentuk pertanggungjawaban penyelenggaraan pendidikan. $^{76}$

\subsubsection{Tujuan Evaluasi Pendidikan}

Tujuan utama melakukan evaluasi dalam proses belajar mengajar adalah "untuk mendapatkan informasi yang akurat mengenai tingkat pencapaian tujuan instruksional oleh siswa sehingga dapat diupayakan tindak lanjutnya". ${ }^{77}$ Sehubungan dengan evaluasi implementai PAK keluarga, maka tujuan evaluasi implementai PAK keluarga adalah untuk mendapatkan informasi yang akurat mengenai implementasi PAK dalam keluarga dan pencapaiannya sehingga dapat diupayakan tindak lanjutnya.

\subsubsection{Fungsi Evaluasi Pendidikan}

Fungsi evaluasi pendidikan mencakup beberapa hal, yaitu: ${ }^{78}$

1) Evaluasi berfungsi selektif.

2) Evaluasi berfungsi diagnostik.

3) Evaluasi berfungsi sebagai penempatan.

${ }^{75}$ Daryanto, Evaluasi Pendidikan

(Jakarta: Rineka Cipta, 2012), 6-7.

${ }^{76}$ Undang-undang Nomor 20 Tahun 2003 tentang Sistem Pendidikan Nasional \& Undangundang No.14 th 2005 tentang Guru \& dosen (Jakarta: VisiMedia, 2008), 4.

\footnotetext{
77 Ibid., 11.

${ }^{78}$ Ibid., 14-16.
} 
4) Evaluasi berfungsi sebagai pengukuran keberhasilan.

\subsubsection{Prinsip, Alat dan Teknik Evaluasi Pendidikan}

\section{(a) Prinsip Evaluasi Pendidikan}

Prinsip evaluasi ada dua, yaitu sistematik obyektif dan independen. Menurutnya kedua prinsip ini wajib diperhatikan oleh evaluator dalam melakukan evaluasi baik evaluasi tanpa riset maupun evaluasi dengan riset. $^{79}$ Evaluasi dapat dilakukan secara internal dan eksternal. Untuk melakukan evaluasi terhadap implementasi PAK keluarga lebih dulu diketahui tujuan PAK keluarga, proses implementasi PAK keluarga, dan evaluasi dengan mengacu pada tujuan yang telah ditetapkan dan proses yang telah dan sedang berlangsung.

\section{(b) Alat Evaluasi Pendidikan}

Dalam melakukan evaluasi ada alat yang digunakan sebagai sarana yang membantu evaluator untuk mencapai tujuan evaluasi dan alat evaluasi tersebut harus mampu mengevaluasi sesuatu dengan hasil seperti keadaan yang dievaluasi. Alat evaluasi disusun berdasarkan tujuan dari suatu penelitian, misalnya: tujuan penelitian untuk mengetahui hasil belajar, maka alat yang digunakan salah satunya adalah test tertulis. ${ }^{80}$ Alat disebut juga instrumen, jadi alat evaluasi sama dengan instrumen evaluasi.

\section{Ali, 181.}

${ }^{80}$ Tim Pengembangan Ilmu Pendidikan FIP-UPI, Ilmu Dan Aplikasi Pendidikan Bagian I: Ilmu Pendidikan Teoretis (Grasindo, t.k. 2007), 112. (c) Teknik Evaluasi Pendidikan

Teknik evaluasi ada dua yaitu teknik nontes dan teknik tes. Teknik nontes meliputi: skala bertingkat (rating scale), kuesioner (questionair), daftar cocok (check list), wawancara (interview), pengamatan (observation), dan riwayat hidup; ${ }^{81}$ sedangkan teknik tes adalah suatu cara yang dilakukan untuk mengetahui kemampuan peserta didik melalui tes seperti tes diagnostik, tes formatif, dan tes sumatif. ${ }^{82}$ ciri-ciri tes yang baik harus memenuhi persyaratan tes seperti: validitas, reliabilitas, objektivitas, praktikabilitas, dan ekonomis. ${ }^{83}$ Teknik-teknik di atas dapat digunakan untuk evaluasi implementasi PAK keluarga dengan menyesuaikan terhadap tujuan evaluasi yang telah ditetapkan.

\subsection{Model-model Evaluasi Pendidikan}

Model evaluasi sangat beragam sesuai dengan cara pemaparannya, namun jika dicermati model-model tersebut tidak jauh berbeda, semuanya bertujuan untuk mengetahui sesuatu objek. Ibrahim dan Ali membedakan evaluasi dalam empat model, yaitu: 1) model pengukuran (measurement model), 2) model persesuaian (congruence model), 3) model evaluasi sistem pendidikan (educational system evaluation model), dan 4) model iluminasi (illumination model). ${ }^{84}$

Arikunto dan Jabar mengutip tulisan Kaufman dan Thomas yang membedakan model evaluasi menjadi delapan, sebagai berikut:

1) Goal Oriented Evaluation Model, dikembangkan oleh Tyler.

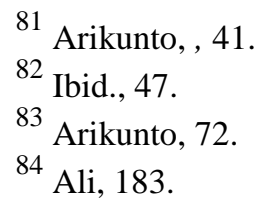


2) Goal Free Evaluation Model, dikembangkan oleh Scriven.

3) Formatif Sumatif Evaluasion Model, dikembangkan oleh Michael Scriven.

4) Countenance Evaluation Model, dikembangkan oleh Stake.

5) Responsive Evaluation Model, Stake.

6) CSE-UCLA Evaluation Model, menekankan pada "kapan" evaluasi dilakukan.

7) CIPP Evaluation Model, dikembangkan oleh Daniel L. Stufflebeam.

8) Discrepancy Model, dikembangkan oleh Provus. ${ }^{85}$

$$
\text { CIPP Evaluation Model }
$$

dikembangkan di Ohio State University dan model evaluasi paling banyak digunakan oleh evaluator. CIPP singkatan dari Context evaluation, Input evaluation, Process evaluation, dan Product evaluation. Menurut Stufflebeam: "Basicly, the CIPP model provides for systematic, principled evaluation of a program's context, inputs, process, and products. Essentially, these four types of evaluation address four foundamental questions:1) What needs to be done? 2) How should it be done? 3) Is it being done? 4) Did it succeed?. Report from the four of evaluation serve both formative and sumative purpose. ${ }^{86}$ Berdasarkan model-model evaluasi di atas, untuk evaluasi implementasi PAK keluarga lebih condong menggunakan evaluasi model CIPP.

\subsection{Subjek dan Sasaran Evaluasi Pendidikan}

Subjek evaluasi adalah orang yang melakukan evaluasi. Dalam dunia pendidikan subjek evaluasi bukan saja

\footnotetext{
${ }^{85}$ Arikunto dan Jabar, 40-41.

${ }^{86}$ Stufflebeam, 21.
}

guru, tetapi dapat melibatkan pihak lain, misalnya: dalam penilaian sikap, subjek evaluasi adalah guru BK atau orang yang sudah dilatih dan ditugaskan untuk melakukan penilaian sikap, sedangkan untuk penilaian kepribadian dapat melibatkan psikolog.

Sasaran sama dengan objek. Sasaran atau objek evaluasi adalah segala sesuatu yang menjadi sasaran dari evaluasi yang ditentukan oleh evaluator, misalnya mengevaluasi hasil belajar, yang jadi sasaran atau objek evaluasi adalah peserta didik. Objek atau sasaran evaluasi adalah "segala sesuatu yang menjadi titik pusat pengamatan karena evaluator menginginkan informasi tentang sesuatu tersebut". ${ }^{87}$ Menggunakan pendekatan di atas, maka Subjek evaluasi PAK keluarga adalah orang tua, gereja, atau peneliti, sedangkan sasaran atau objek untuk evaluasi implementasi PAK keluarga, antara lain: pendidik, peserta didik, kurikulum dan bahan ajar, metode, kegiatan, waktu dan tempat pelaksanaan, sarana dan prasarana, dan pendanaan.

\subsection{Langkah-langkah Evaluasi}

Evaluasi adalah suatu kegiatan yang dilakukan secara terus meneru. Untuk itu, evaluator harus mengetahui dan memahami langkah-langkah yang akan dilakukan dalam evaluasi. Ada pun langkah-langkah pokok dalam evaluasi sebagai berikut: a) Perencanaan (Planning), b) Pengumpulan Data, c) Verifikasi Data, Pengolahan Data, d) Penafsiran Data atau Kesimpulan, dan e) Membuat Laporan Evaluasi.

\section{Metode Penelitian}

Metode penelitian ini adalah metode penelitian evaluasi implementasi

${ }^{87}$ Arikuto, 34. 
dengan pendekatan penelitian kualitatif yang bersifat deskriptif. Michael Quinn Patton mengatakan: evaluasi implementasi adalah upaya untuk mengetahui tingkat efektifitas satu program setelah diterapkan secara penuh dengan mengetahui bagaimana dan pada tingkatan mana program telah nyatanyata diterapkan. ${ }^{88}$ Melalui evaluasi implementasi para pengambil keputusan dapat mengetahui apa yang terjadi dalam program dan bagaimana program tersebut berkembang. ${ }^{89}$

Pendekatan kualitatif bertujuan untuk mendapat gambaran secara detail mengenai hal-hal yang akan diteliti. Menurut Moleong, penelitian kualitatif adalah penelitian yang bermaksud untuk memahami fenomena tentang apa yang dialami oleh subjek penelitian, misalnya: perilaku, persepsi, motivasi, tindakan, dan lain-lain, secara holistik, dan dengan cara deskripsi dalam bentuk kata-kata dan bahasa pada suatu konteks khusus yang alamiah dan dengan memanfaatkan berbagai metode alamiah. ${ }^{90}$ Penelitian kualitatif adalah jenis penelitian yang tidak menggunakan angka-angka dalam temuannya atau data tidak diperoleh berdasarkan statistik. Penelitian kualitatif bertujuan mengungkapkan gejala secara holistik-kontekstual di mana pengumpulan data berjalan secara alami dan peneliti berfungsi sebagai instrumen kunci. ${ }^{91}$ Penelitian kualitatif yang bersifat deskriptif artinya data yang

${ }^{88}$ Michael Quinn Patton, Metode

Evaluasi Kualitatif, (Yogyakarta: Pustaka Pelajar, 2009), 37.

89 Ibid., 38.

${ }^{90}$ Lexy J. Moleong, Metodologi

Penelitian Kualitatif, (Bandung: Remaja Rosda Karya, 2014), 4.

91 Eko Sugiarto, Menyusun Proposal

Penelitian Kualitatif:Skripsi dan Tesis, (Yogyakarta: Suka Media, 2015), 8. dikumpulkan berupa kata-kata atau tulisan dan perilaku orang-orang yang diteliti, tidak menekankan pada angka.

Dalam mengumpulkan data, peneliti menggunakan evaluasi model CIPP khusunya pada variabel implementasi PAK keluarga di GKRI JDC, model ini dipilih karena sistematis. Evaluasi model CIPP terdiri dari evaluasi konteks (context), evaluasi masukan (input), evaluasi proses (process), dan evaluasi hasil (product).

Evaluasi model CIPP dalam penelitian ini lebih jelas digambarkan sebagai berikut: 


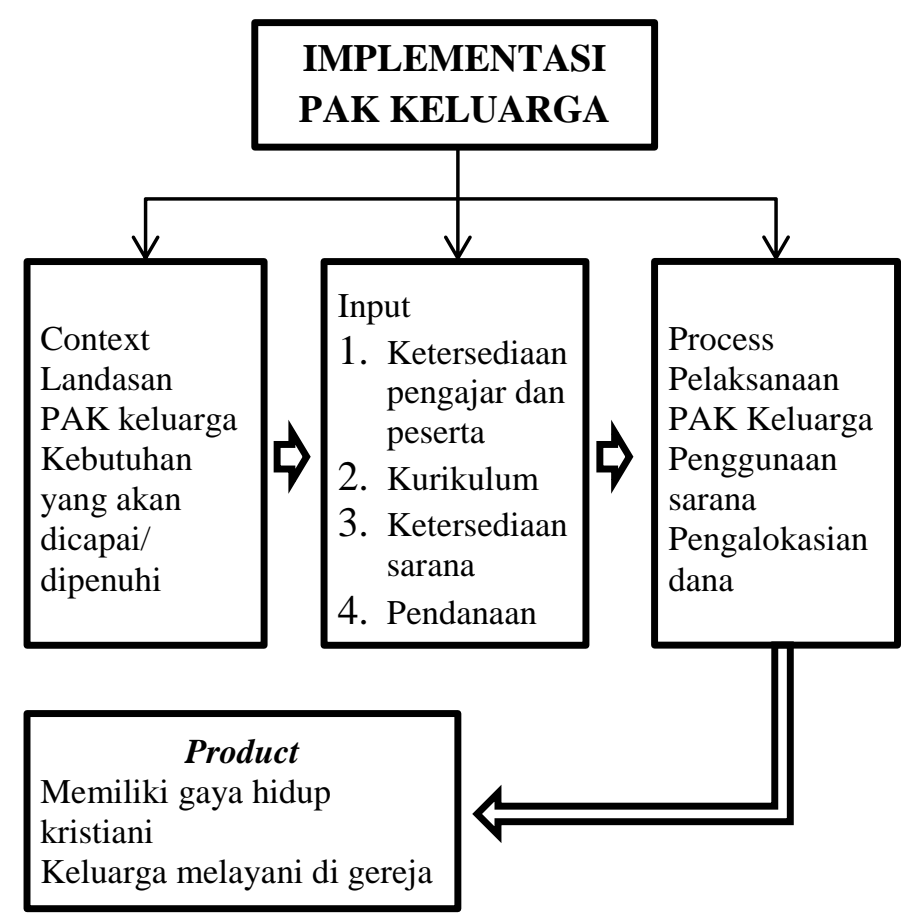

\section{Gambar 1. Evaluasi Model CIPP}

Penelitian ini dilakukan di Gereja Kristus Rahmani Indonesia Jemaat Diaspora Cawang (GKRI JDC) dengan alamat sekretarian J1. Usman Harun No. 45 RT. 02/05 Kelurahan Kebon Pala Jakarta Timur. Penelitian ini dilakukan selama empat bulan yakni bulan Maret sampai dengan Juni 2018. Teknik pengumpulan data dilakukan dengan studi pustaka dan wawancara. Tinjauan Pustaka adalah kegiatan untuk mengumpulkan data-data berupa informasi dari buku-buku, jurnal, majalah, dokumen dan literatur lainnya yang bermanfaat untuk menyusun landasan teoritis sebagai tolak ukur dalam menganalisis penelitian lapangan. Tinjauan pustaka selayaknya menggunakan sumber-sumber terbaru, sumber-sumber yang relevan, banyak dan berbobot. ${ }^{1}$ Wawancara adalah tanya

\footnotetext{
${ }^{1}$ Mayang Sari Lubis, 10.
}

jawab peneliti dengan manusia sumber. ${ }^{2}$ Peneliti menggunakan tiga pendekatan, yaitu 1) wawancara percakapan informal; 2) wawancara umum; dan 3) wawancara terbuka yang dibakukan. ${ }^{3}$ Ketiga pendekatan ini dikombinasikan untuk memperoleh data yang diharapkan.

Sampel dalam penelitian ini ditentukan dengan menggunakan teknik purposive sampling (sampel bertujuan), di mana seseorang dapat dijadikan sampel didasarkan pada tujuan tertentu. ${ }^{4}$ Adapun kriteria sampel adalah sebagai berikut: 1) Telah mengimplementasikan PAK keluarga. 2) Memiliki anak dan tinggal bersama orang tua. 3) Anak

\section{Tim Penyusun Kamus Pusat Pembinaan} dan Pengembangan Bahasa, Kamus Besar Bahasa Indonesia, ed. 2, 1127.

\footnotetext{
${ }^{3}$ Moleong, 185, 194.

${ }^{4}$ Sugiyono, Metode Penelitian
} Pendidikan, (Bandung: Alfabeta, 2012), 96. 
minimal duduk di bangku Sekolah Dasar (SD). Analisi data dalam penelitian kualitatif dilakukan dalam tiga tahap yakni sebelum memasuki lapangan, selama di lapangan, dan setelah selesai di lapangan. ${ }^{5}$ Tahapan aktivitas analisis data, yakni: 1) data reduction (reduksi data), 2) data display (penyajian data), 3) conclusion drawing/verification (penarikan kesimpulan/verifikasi).

\section{Temuan Penelitian Dan Analisis}

\subsection{Temuan Penelitian dan Pembahasan}

Dalam penelitian yang dilakukan penulis ditemukan beberapa hal berikut:

- Keluarga-keluarga di GKRI Jemaat Diaspora Cawang Jakarta Timur memahami PAK keluarga merupakan hal yang sangat penting dalam keluarga dan menjadi hal utama.

- Keluarga-keluarga di GKRI Jemaat Diaspora Cawang Jakarta Timur belum dipahami secara mendalam landasan alkitabiah dan hukum PAK keluarga.

- Dalam mengimplementasikan PAK keluarga, keluarga-keluarga di GKRI Jemaat Diaspora Cawang Jakarta Timur melibatkan seluruh anggota keluarga.

- Dalam keluarga-keluarga di GKRI Jemaat Diaspora Cawang Jakarta Timur orang tua menjadi pengajar atau yang bertanggungjawab penuh terhadap implementasi PAK keluarga.

- Keluarga-keluarga di GKRI Jemaat Diaspora Cawang Jakarta Timur menggunakan berbagai sanara yang mendukung implementasi PAK keluarga seperti: Alkitab, renungan harian, gitar.

\footnotetext{
${ }^{5}$ Ibid., 336.
}

- Keluarga-keluarga di GKRI Jemaat Diaspora Cawang Jakarta Timur menggunakan berbagai metode dalam mengimplementasikan PAK keluarga.

- Keluarga-keluarga di GKRI Jemaat Diaspora Cawang Jakarta Timur menggunakan Alkitab sebagai kurikulum dan bahan ajar dalam mengimlementasikan PAK keluarga. Belum ada kurikulum khusus PAK keluarga yang disusun baik oleh keluarga maupun gereja.

- Keluarga-keluarga di GKRI Jemaat Diaspora Cawang Jakarta Timur belum membuat anggaran dana untuk mendukung implementasi PAK keluarga, namun setiap ada kebutuhan terkait PAK keluarga dana selalu ada.

- Keluarga-keluarga di GKRI Jemaat Diaspora Cawang Jakarta Timur belum melakukan evaluasi secara khusus terhadap implementasi PAK keluarga yang mencakup semua unsur PAK keluarga. Adapun evaluasi yang dilakukan selama ini hanya berupa pengamatan terhadap perilaku anak-anak dengan menjadikan Alkitab sebagai tolak ukurnya.

\subsection{Analisis Teologis dan Pedagogis}

\subsubsection{Implikasi Teologis}

PAK Keluarga merupakan perintah Allah yang harus dilaksanakan oleh keluarga-keluarga Kristen secara turun temurun. Dalam Efesus 4:6 jelas dikatakan bahwa orang tua khususnya ayah harus mendidik anak-anaknya sesuai jalan yang patut baginya, yaitu sesuai dengan ajaran Tuhan. Untuk itu, orang tua Kristen harus lebih sadar akan tugas dan tanggung jawab ini dan tidak menyerahkan pendidikan anak-anaknya kepada sekolah dan gereja. Orang tua 
bertugas mendidik, membimbing, mengajak dan membawa anak-anak untuk takut akan Allah dengan berbagai cara guna pemenuhan PAK bagi anakanak. Mazmur 119:9 menyatakan bahwa orang muda dapat mempertahankan kelakuannya bersih yaitu jika ia memiliki pengetahuan dan pemahaman akan firman Tuhan. Pengajaran di sekolah dan gereja terbatas, untuk itu, orang tua harus memberikan waktunya untuk mendidik anak-anaknya di rumah supaya mengetahui dan memahami firman Tuhan serta mampu menerapkannya dalam kehidupannya sehari-hari.

Praktik PAK keluarga mengacu pada apa yang telah dilakukan oleh keluarga-keluarga bangsa Israel dalam keluarganya. Mereka sangat mengutamakan pendidikan iman anakanaknya di atas segalanya, itu sebabnya anak-anak Israel memiliki pendidikan yang wajib tentang hukum Taurat dan kitab para nabi. Pendidikan agama bagi orang Israel adalah kewajiban dan tidak bisa dilepaskan dari kehidupan mereka sehari-hari. Mereka mengajar anakanaknya dengan cara berulang-ulang dengan menggunakan berbagai metode (Ul. 6:4-9). Demikian juga dengan keluarga Kristen, PAK keluarga merupakan kewajiban dan harus nyata dalam kehidupan sehari-hari, dengan demikian keluarga Kristen akan menjadi saksi di tengah dunia. Mendidik anak itu perlu sebagaimana yang dituliskan peAmsal dalam Amsal 22:6 "Didiklah orang muda menurut jalan yang patut baginya, maka pada masa tua pun ia tidak akan menyimpang dari jalan itu", dari ayat ini dapat disimpulkan bahwa kehidupan anak-anak pada masa depan ditentukan oleh pendidikan yang diterimakanya pada masa anak-anak. Amsal 29:17 juga menyatakan bahwa anak-anak yang mendapatkan didikan akan membawa kebahagiaan bagi orang tuanya.

\subsubsection{Implikasi Pedagogis}

PAK harus dilakukan dalam keluarga karena PAK itu penting dan memberi dampak positif terhadap perkembangan anak, baik perilaku maupun spiritualitasnya. PAK keluarga membawa perubahan perilaku bagi seluruh anggota keluarga (orang tua dan anak) dan mengarah pada pendewasaan iman dan memiliki kebijaksanaan dalam menyikapi kehidupan. Untuk itu, diperlukan berbagai cara yang menarik dalam melaksanakan PAK keluarga untuk merangsang minat dan keinginan anak mengikutinya. Model-model pembelajaran yang bervariasi akan membuat anak tertarik dan dengan sendirinya akan melakukannya.

Menurut psikologi perkembangan, setiap anak memiliki keunikan, karakternya masing-masing dan tingkat perkembangan yang berbeda-beda. Menyikapi hal ini, orang tua harus berusaha mengenal dan mengerti setiap kepribadian anaknya. Hal ini dilakukan agar orang tua bisa mempengaruhi perkembangan kepribadian anak kearah gambaran kepribadian yang dikehendaki pada setiap tahap perkembangannya sampai anak tumbuh dewasa. ${ }^{6}$ Selain mengenal kepribadian anak, dibutuhkan strategi dan metode yang tepat dalam mengajarkan PAK keluarga kepada anak. Orang tua harus memahami banyak hal untuk membantunya dalam melaksanakan PAK dalam keluarga, antara lain:

1. Memahami psikologi perkembangan

\footnotetext{
${ }^{6}$ Singgih D. Gunarsa, Dasar dan Teori Perkembangan Anak (Jakarta: BPK Gunung Mulia, 2008), 204.
} 
anak, orang tua yang memiliki pemahaman yang luas tentang psikologi perkembangan anak, akan dengan mudah melakukan pendekatan dan pengajaran kepada anak, dengan demikian pendidikan anak akan terhindar dari kekeliruan. Menurut Sumiyati ningsih, ada empat manfaat bagi pendidik (orang tua) mempelajari psikologi perkembangan, yaitu:

- Pendidik dapat menghadapi peserta didik dengan tepat, sesuai dengan sifat-sifat yang khas yang diungkapkan oleh peserta didik.

- Pendidik dapat memilih dan menentukan tujuan materi dan strategi pembelajaran sesuai dengan tingkat kemampuan intelektual peserta didik (kognitif, moral atau etika, ego, dan iman).

- Pendidik dapat menghadapi peserta didik dengan benar sekaligus dapat turt membentuk tingkah laku yang benar karena pendidik menyadari yang dihadapi adalah manusia yang sedang dalam proses perkembangan.

- Pendidik dapat menghindari pemahaman yang keliru tentang peserta didik, khususnya mengenai aspek-aspek yang mempengaruhi proses perkembangan peserta didik dan kemampuannya dalam belajar. ${ }^{7}$

2. Memahami bermacam-macam metode mengajar, mengajar anak untuk memiliki kehidupan yang sesuai firman Tuhan bukanlah hal yang mudah, untuk itu, orang tua

\footnotetext{
${ }^{7}$ Dien Sumiyatiningsih, Mengajar dengan Kreatif dan Menarik (Yogyakarta: ANDI, 2012), 117.
}

perlu memahami berbagai metode mengajar dan mampu menggunakannya, dengan demikian pengajaran yang diberikan orang tua dapat diterima dan dipahami oleh anak secara tepat dan benar.

Orang tua harus memberi perhatian yang serius terhadap pelaksanaan PAK keluarga karena tujuan dari PAK itu sendiri bukan hanya untuk kehidupan di dunia ini tetapi juga untuk hidup sesudah kematian. Artinya, jika anak-anak mendapatkan pengajaran yang baik dan benar tentang PAK dalam keluarga, itu akan mengantar mereka mengenal siapa Tuhan dan juruselamat mereka, tentunya melalui pengalaman dan pekerjaan Roh Kudus anak-anak akan memiliki iman pada Yesus Kristus dan mengakui-Nya sebagai Juru selamat.

\section{Kesimpulan}

1. Keluarga di GKRI Jemaat Diaspora Cawang Jakarta Timur sudah memahami PAK keluarga. Hal ini terlihat dari pernyataan-pernyataan yang disampaikan informan bahwa PAK keluarga merupakan hal yang penting dan merupakan pendidikan mendasar bagi anak-anak supaya mereka mengetahui firman Allah dan memiliki pengenalan akan Allah dengan maksud anak-anak memiliki kehidupan yang sesuai dengan firman Allah.

2. Keluarga di GKRI JDC telah melaksanakan PAK keluarga dengan baik untuk memenuhi kebutuhan rohani keluarga, di mana orang tua sebagai pendidik dan seluruh anggota keluarga sebagi peserta didik. Implementasi PAK keluarga yang dilakukan berupa saat teduh dan ibadah keluarga yang di dalamnya memuat berdoa, baca Alkitab, dan memuji Tuhan. Selain 
melakukan saat teduh dan ibadah keluarga, mereka juga melaksanakan PAK keluarga melalui kehidupan sehari-hari, yakni melalui peristiwa kehidupan dan teladan orang tua. Keluarga juga menggunaan berbagai sarana, metode dan strategi dalam mengupayakan PAK keluarga. Dari upaya yang dilakukan (melaksanakan PAK keluarga), keluarga memperoleh hasil yang tergolong baik, yakni anak-anak memiliki kehidupan yang tertib, tidak terpengaruh dengan pergaulan buruk, suka baca Alkitab, suka berdoa, suka ke gereja, ikut melayani di gereja, dan keluarga semakin kuat. Di tengah keberhasilan keluarga dalam melaksanakan PAK keluarga ditemukan beberapa hal yang perlu ditingkatkan dan dilengkapi oleh keluarga untuk meningkatkan implementasi PAK keluarga. Hal-hal yang dimaksud adalah:

a. Pemahaman tentang landasan alkitabiah dan landasan hukum PAK keluarga.

b. Penggunaan sarana, orang tua diharapkan mampu menggunakan sarana yang ada disekitar keluarga untuk meningkatkan PAK keluarga karena ada banyak sarana yang dapat digunakan, seperti alam, binatang, tumbuhan, bendabenda langit, perabot rumah tangga, dan lain sebagainya, namun belum digunakan keluarga.

c. Pengadaan kurikulum PAK keluarga yang kontekstual (berciri GKRI JDC), yang tersusun dengan baik dan sudah dibukukan.

d. Pengadaan bahan ajar yang sudah dirancang sedemikian rupa untuk jangka waktu tertentu.

e. Membuat anggaran dana PAK keluarga untuk memperlancar proses PAK keluarga.

f. Pengadaan buku panduan evaluasi PAK keluarga. Hal ini dibutuhkan sebagai pedoman bagi keluarga dalam melaksanakan evaluasi implementasi PAK keluarga.

3. Keluarga di GKRI Jemaat Diaspora Cawang belum pernah melakukan evaluasi terhadap implementasi PAK keluarga yang mencakup seluruh unsur PAK keluarga, seperti pendidik, kurikulum, bahan ajar, waktu, tempat, metode, strategi, dan pendanaan. Keluarga hanya mengevaluasi peserta didik melalui observasi atau pengamatan yaitu pada perubahan tingkahlaku yang ditunjukkan anak-anak dalam kehidupan sehari-hari.

\section{Daftar Pustaka}

Alkitab, Jakarta: Lembaga Alkitab Indonesia, 2005.

Antoni. Michael J., Foundations of Ministry. Malang: Gandum Mas, 2012.

Boehlke. Robert R., Sejarah Perkembangan

Pikiran dan Praktek Pendidikan Agama Kristen Dari Yohanes Amos Comenius Sampai Perkembangan PAK Di Indonesia, Jakarta: BPK Gunung Mulia, 2005.

Clark. Robert E., Johnson. Lin, Sloat. Allyn K., Christian Education Foundations for The Future, Chicago: Moody Publishers, 1991.

Darmawijaya, Mengarungi Hidup Berkeluarga, Yogyakarta: Kanisius, 2011.

Daryanto, Evaluasi Pendidikan, Jakarta: Rineka Cipta, 2012. 
Daulay. Richard M., Menganal Gereja Methodis Indoensia, Jakarta: BPK Gunung Mulia, 2004.

Gunarsa. Singgih D., Dasar dan Teori Perkembangan Anak, Jakarta: BPK Gunung Mulia, 2008.

Holmen. Mark, Church + Home, Bandung: Pionir Jaya, 2016.

Lexy J. Moleong, Metodologi Penelitian Kualitatif, Bandung: Remaja Rosda Karya, 2014.

Nainggolan. John M., Menjadi Guru Agama Kristen, Bandung: Gerakan Infomedia, 2006.

Patton. Michael Quinn, Metode Evaluasi Kualitatif, Yogyakarta: Pustaka Pelajar, 2009.

Pazmiño. Robet W., Foundational Issues in Christian Education 3rd ed., Amerika: Biker Academic, 2008.

Putra. Andri Rizki, Orang Jujur Tidak Sekolah, Yogyakarta: Penerbit Bentang, 2014.

Riemer. G., Ajarlah Mereka, Jakarta: Yayasan Komunikasi Bina Kasih/OMF, 2006.

Robert W. Pazmiño, Fondasi Pendididkan Kristen: Sebuah Pengantar dalam Perspektif Injil (Bandung: STT Bandung dan BPK Gunung Mulia, 2012), 211-212.

Rupp. Anne Neufeld, Tumbuh-Kembang Bersama Anak: Menuntun Anak Menuju Pertumbuhan Emosional, Moral, dan iman, Jakarta: BPK Gunung Mulia, 2009.

Sairin. Weinata edit, Himpunan Peraturan Dibidang Pendidikan, Jakarta: Jala Permata Aksara, 2010.

Peny. Himpunan Peraturan di Bidang Pendidikan, Jakarta: Media Prima Aksara, 2012.

Satiadarma. Monty P., Persepsi Orang tua Membentuk Perilaku Anak: Dampak Pygmalion di dalam Keluarga, Jakarta: Yayasan Pustaka Obor Indonesia, 2001.
Sidjabat. B.S., Menjadi Guru yang Profesional: Sebuah Perspektif Kristiani, Bandung: Kalam Hidup, 2000.

, Strategi Pendidikan Kristenedisi revisi, Yogyakarta: ANDI, 1996.

Sugiarto. Eko, Menyusun Proposal Penelitian Kualitatif:Skripsi dan Tesis, Yogyakarta: Suka Media, 2015.

Sugiyono, Metode Penelitian Pendidikan, Bandung: Alfabeta, 2012.

Sumiyatiningsih. Dien, Mengajar dengan Kreatif dan Menarik, Yogyakarta: ANDI, 2012.

Tim Pengembang Ilmu Pendididikan FIPUPI, Ilmu dan Implikasi Pendidikan Bagian 4 Pendidikan Lintas Bidang, tk: IMTIMA, 2007.

Tim Pengembangan Ilmu Pendidikan FIPUPI, Ilmu Dan Aplikasi Pendidikan Bagian I: Ilmu Pendidikan Teoretis, Grasindo, t.k. 2007.

Tim Penyusun Kamus Pusat Pembinaan dan Pengembangan Bahasa, Kamus Besar Bahasa Indonesia, Jakarta: Balai Pustaka, 1996.

Tim Penyusun Kamus Pusat Pembinaan dan Pengembangan Bahasa, Kamus Besar Bahasa Indonesia, ed. 3-cet. 1, Jakarta: Balai Pustaka, 2001.

Undang-undang Nomor 20 Tahun 2003 tentang Sistem Pendidikan Nasional \& Undang-undang No.14 th 2005 tentang Guru \& dosen, Jakarta: VisiMedia, 2008.

http://repository.petra.ac.id/15665/1/pdfKarakter_Pendidikan_Kristen_MAG DA_to_PK.pdf.

http://sttintheos.ac.id/ejournal/index.php/antusias/article/dow nload/23/22. 